\title{
INFLUENCE OF COMPOST AND IRRIGATION SYSTEMS ON THE GROWTH INDICES AND YIELD OF ONION (Allium cepa L.)
}

\author{
${ }^{1}$ Isa, H. M. and ${ }^{2}$ Waiya, M.A. \\ ${ }^{1}$ Department of Agronomy, Faculty of Agriculture, Bayero University, P. M. B. 3011, Kano, Nigeria. \\ Department of Crop Science, Kano University of Science and Technology Wudil, Kano State \\ *corresponding author email: hmisa.agr@buk.edu.ng
}

\begin{abstract}
Field trial was conducted during the 2017 dry season from March to June at Bayero University, Kano and Birji village both in Sudan savannah to determine the effect of compost rates and irrigation intervals on the growth and yield of onion (Allium cepa L.). The treatments were conducted in five rates of compost $\left(0 \mathrm{t} \mathrm{ha} \mathrm{h}^{-1}, 5 \mathrm{tha}, 10 \mathrm{tha}, 15 \mathrm{t}\right.$ $h^{-1}$ and $20 t h^{-1}$ ) and three irrigation intervals (5, 10 and 15 days). The treatments were laid out in a split plot design and replicated three times. Irrigation intervals were assigned to the main plot while compost rates were assigned to the sub plot. The gross plot size was $1.5 \mathrm{~m} \times 2.0 \mathrm{~m}\left(3.0 \mathrm{~m}^{2}\right)$ consisting of 10 rows of $2 \mathrm{~m}$ length. Data on growth and yield parameters were collected, weighed and subjected to analysis of variance (ANOVA). Treatment means were separated using Student-Newman-Keuls Test. The result showed that compost rates and irrigation intervals had significant effect on crop growth rate, relative growth rate, net assimilation rate and cured bulb yield. Application of $10 \mathrm{t} \mathrm{ha} \mathrm{a}^{-1}$ of compost had the heaviest cured bulb yield. Interactions between compost rates and irrigation intervals were significant on all the measured parameters as well as the cured bulb yield of onion at both locations. The optimum rate of compost was $15 t$ ha $^{-}$ 1 at both locations, while that of irrigation intervals were10 and 5 days for BUK and Birji village, respectively. Therefore, these levels were recommended to be used by farmers of the study areas.
\end{abstract}

Key words: Crop growth rate, Relative growth rate, Onion, Compost, Irrigation

\section{INTRODUCTION}

Onion (Allium cepa L.) belongs to the family Alliaceae. Other members belonging to the same family include shallot, common garlic and leek onion and it is one of the most commonly consumed vegetables crops in the world with China being the number one producer of Onions while Japan and India are the second highest producers of green Onions and dry Onions respectively. Nigeria ranks sixth among the top ten producers of green Onions and Eleventh in terms of dry Onion production. According to Hasegawa et al., (2001) onion originated from central Asia and is cultivated in many countries around the world. In terms of income, onion is the second most important vegetable crop after tomatoes in the world. Onion cultivation in Nigeria is confined to the semi-arid Northern Guinea and Sudan Savannah zones where it is normally transplanted in November and harvested in April in the cool dry season under irrigation. The soils in this area are mostly low in nutrients due to low matter content which lowers yields (Amans, 1989). Several antioxidant compounds, mainly polyphenols and sulphur containing compounds have been found in onion (Nuutila et al., 2003). Recently, onion is being used by processing industry to greater extent for preparing dehydrated forms like powder and flakes (Sarsavadia et al., 1999).Low soil fertility has been identified as one of the major problems facing small scale farmers in the tropics. The low Fertility is caused by continuous cropping without additional soil fertility inputs (Mofuka et al., 2007).Organic fertilizers like farmyard manure, vermin compost, neem cake, compost and poultry manure are very popular among the farmers and easily produced, or reduce and eliminate the adverse effects of synthetic fertilizers and pesticides on human health and environment, new agricultural practices have been developed (Chowdhury, 2004).If shortage of readily available soil water is eliminated and the technological and biological characteristics of the crop are taken into account, it is possible to achieve high and stable yields of irrigated onions, at the level of $40 \mathrm{t} \mathrm{ha}^{-1}$ or higher (Pejic et. al., 2011). Many growers obtain much lower yields, primarily because of inadequate irrigation scheduling (Mohamed and 
BAJOPAS Volume 14 Number 1, June, 2021 Fahal, 2006). The research was aimed in determining the effect of compost rates and irrigation intervals on the growth and yield of Onion as well as the optimum compost rate and appropriate irrigation scheduling that gave the highest yield of Onion.

\section{MATERIALS AND METHODS}

This research work was conducted during 2017dry season from March to June at two different locations: Teaching and Research Farm of Faculty of Agriculture, Bayero University, Kano $\left(11^{0} 58^{\mathrm{I}} \mathrm{N}, 8^{0} 25^{\mathrm{I}} \mathrm{E}\right)$ and Birji village $\left(11^{0} 46^{\prime} 38^{\prime \prime} N 8^{0} 17^{\prime} 18^{\prime \prime} E\right)$ both within the Sudan Savannah Ecological Zone of Nigeria. The treatments consisted of five rates of compost $(0$, $5,10,15 a n d 20 \mathrm{t} \mathrm{ha}^{-1}$ ) and three irrigation intervals $(5,10$ and 15 days). These were laid out in split plot design and replicated 3 times. Irrigation intervals were assigned to the main plots while compost was assigned to sub plots. The gross plot size was $1.5 \mathrm{~m} \times 2.0 \mathrm{~m}\left(3.0 \mathrm{~m}^{2}\right)$ consisting of 10 rows of $2 \mathrm{~m}$ length, while the net plot size was $0.9 \mathrm{~m} \times 2.0 \mathrm{~m}\left(1.8 \mathrm{~m}^{2}\right)$ consisting of 6 innermost rows. The variety of the Onion that was used is known as Red creole which is a medium maturing, open pollinated, short day red onion. It is well adapted and widely planted. The outer scale is medium dark red, the rings are tight and red through to the center of the bulb, the bulb tastes slightly pungent. The bulbs are attractive and stores well.

The experimental fields were thoroughly ploughed, harrowed, leveled and worked into a fine tilth prior to transplanting and divided into sunken beds $1.5 \mathrm{~m} \times 2.0 \mathrm{~m}\left(3.0 \mathrm{~m}^{2}\right)$. Each plot was separated from another by $0.5 \mathrm{~m}$ border. The space between main plots was $1.5 \mathrm{~m}$ while the space between replicates was $1 \mathrm{~m}$. Before removing the seedlings from the nursery, the beds in the fields were thoroughly irrigated and seedlings were transplanted at spacing of $15 \mathrm{~cm}$ $x 10 \mathrm{~cm}$. The compost was prepared in compost bin at Soil Science Department, BUK using cow dung, poultry litter, cereal by-product (rice bran), sawdust, vegetables scraps, fresh and dry biomass by putting the materials in the following sequence or layers: first layer of material which was difficult to decompose consisted of twigs and stalks, second layer of material which was easy to decompose was fresh green biomass, third layer was cow dung; poultry manure was at the fourth layer, followed by the rest of the materials which were laid over one another. Each layer was wet lightly with the content of anaerobic digester to obtain the micro- organisms needed for the composting process. The compost heap was watered to maintain moisture content and turned over at regular intervals with a shovel to improve aeration and decomposition of the heap. Eight weeks was allowed for composting process and an additional one week was allowed for curing. The compost was applied as per treatments to the plot during land preparation two weeks before planting to facilitate decomposition. A light irrigation was applied just after the transplanting and subsequent irrigation was given at an interval of 5,10 and 15 days as per treatment. Data were collected on dry matter, crop growth rate, net assimilation rate and cured bulb yield.

\section{RESULTS}

The effect of compost rates and irrigation intervals on crop growth rate of onion at BUK and Birji during 2017 dry season was presented in Table 1. There were significant differences between compost rates on crop growth rate across the sampling periods except 12WAT, at BUK. At BUK, at 8WAT, application of $15 \mathrm{t} \mathrm{ha}^{-1}$ of compost produced plants with higher crop growth rate $\left(0.31 \mathrm{~g} \mathrm{wk}^{-1}\right)$ although statistically at par with 5,10 and $20 \mathrm{t} \mathrm{ha}^{-1}$ of compost (0.27, 0.26 and $0.29 \mathrm{~g} \mathrm{wk}^{-1}$, respectively) while those that received $0 \mathrm{t} \mathrm{ha}{ }^{-1}$ of compost produced plants with lower crop growth rate $\left(0.20 \mathrm{~g} \mathrm{wk}^{-1}\right)$ (Table 1). However, at Birji, at 8WAT, a similar trend was observed (Table 1). At 12WAT, at the same location, application $20 \mathrm{t} \mathrm{ha}^{-1}$ of compost had produced plants with higher crop growth rate $\left(0.41 \mathrm{~g} \mathrm{wk}^{-1}\right)$ while those that received $0 \mathrm{t}$ $\mathrm{ha}^{-1}$ produced plants with lower crop growth rate $\left(0.15 \mathrm{gwk}^{-1}\right)$ (Table 1). Irrigation intervals had significant effect on crop growth rate of onion across the sampling periods except at 12WAT, at Birji. At BUK, at 8WAT, irrigation at 5 days interval produced plants with higher crop growth rate $\left(0.33 \mathrm{~g} \mathrm{wk}^{-1}\right)$ although statistically at par with 10 days interval $\left(0.31 \mathrm{gwk}^{-1}\right)$ while those that received 15 days of irrigation interval produced plants with lower growth rate $(0.15 \mathrm{~g}$ $\mathrm{wk}^{-1}$ ) (Table 1). At 12WAT, at the same location irrigation at 10 days interval produced plants with higher crop growth rate $\left(0.38 \mathrm{~g} \mathrm{wk}^{-1}\right)$ although statistically at par with 5 days interval $\left(0.34 \mathrm{~g} \mathrm{wk}^{-1}\right)$ while those that received 15 days of irrigation interval produced plants with lower crop growth rate $\left(0.25 \mathrm{~g} \mathrm{wk}^{-1}\right)$ (Table 1$)$. However, at Birji, a similar trend was observed (Table 1). The interaction between compost rates and irrigation intervals on crop growth rate of onion was significant across the sampling periods except at 12WAT, at BUK (Table 1). 
BAJOPAS Volume 14 Number 1, June, 2021

Table 2 shows the effect of compost rates and irrigation intervals on relative growth rate of onion at BUK and Birji in 2017 dry season. There were significant differences between compost rates on relative growth rate across the sampling periods at both locations. At BUK, at 8WAT, application of $20 \mathrm{t} \mathrm{ha}^{-1}$ of compost produced plants with higher relative growth rate $\left(0.35 \mathrm{~g} \mathrm{~g}^{-1} \mathrm{wk}^{-1}\right)$ while those that received $0 \mathrm{t}$ $\mathrm{ha}^{-1}$ of compost produced plants with lower relative growth rate $\left(0.13 \mathrm{~g} \mathrm{~g}^{-1} \mathrm{wk}^{-1}\right)$ (Table 2). At 12WAT, a similar trend was observed although statistically at par with $15 \mathrm{t} \mathrm{ha}^{-1}$ of compost (Table 2). However, at Birji, at 8WAT, application of $15 \mathrm{ha}^{-1}$ of compost produced plants with higher relative growth rate $\left(0.45 \mathrm{~g} \mathrm{~g}^{-}\right.$ ${ }^{1} \mathrm{wk}^{-1-}$ ) while those that received $0 \mathrm{t} \mathrm{ha}{ }^{-1}$ of compost produced plants with lower relative growth rate $\left(0.14 \mathrm{~g} \mathrm{~g}^{-1} \mathrm{wk}^{-1}\right)$ (Table 2). At 12WAT, at the same location, application of $20 \mathrm{t}$ $\mathrm{ha}^{-1}$ of compost produced plants with higher relative growth rate $\left(0.12 \mathrm{~g} \mathrm{~g} \mathrm{~g}^{-1} \mathrm{wk}^{-1}\right)$ although statistically at par with $5 \mathrm{t} \mathrm{ha}^{-1}$ of compost $(0.11$ $\mathrm{g} \mathrm{g}^{-1} \mathrm{wk}^{-1}$ ) while those that received $0 \mathrm{t}$ ha ${ }^{1}$ produced plants with lower relative growth rate $\left(0.04 \mathrm{~g} \mathrm{~g}^{-1} \mathrm{wk}^{-1}\right.$ ) (Table 2). Irrigation intervals had significant effect on relative growth rate of onion across the sampling periods except at 12WAT, at Birji. At BUK, at 8WAT, irrigation at 10 days interval produced plants with higher relative growth rate $\left(0.30 \mathrm{~g} \mathrm{~g}^{-1} \mathrm{wk}^{-1}\right)$ although statistically at par with 5 days interval $\left(0.27 \mathrm{~g} \mathrm{~g}^{-1}\right.$ $\mathrm{wk}^{-1}$ ) while those that received 15 days of irrigation interval produced plants with lower relative growth rate $\left(0.15 \mathrm{~g} \mathrm{~g}^{-1} \mathrm{wk}^{-1}\right)$ (Table 2). At 12WAT, at the same location, a similar trend was observed (Table 2). However, at Birji, also a similar trend was observed (Table 2). The interaction between compost rates and irrigation intervals on relative growth rate of Onion was significant across the sampling periods except at 12WAT, at Birji (Table 2).

Table 3 shows the effect of compost rates and irrigation intervals on net assimilation rate of onion at BUK and Birji in 2017 dry season. There were significant differences between compost rates onnet assimilation rate of onion across the sampling periods except at 12WAT, at BUK (Table 3). At BUK, at 8WAT, application of $5 \mathrm{t}$ $\mathrm{ha}^{-1}$ of compost produced plants with higher net assimilation rate $\left(0.00098 \mathrm{~g} \mathrm{~cm}^{-2} \mathrm{wk}^{-1}\right)$ while those that received $0 \mathrm{t} \mathrm{ha}^{-1}$ of compost produced plants with lower net assimilation rate $(0.00036$ $\mathrm{g} \mathrm{cm}^{-2} \mathrm{wk}^{-1}$ ) (Table 3). However, at Birji, at
8WAT, application of $15 \mathrm{t} \mathrm{ha}^{-1}$ of compost produced plants with higher net assimilation rate $\left(0.00128 \mathrm{~g} \mathrm{~cm}^{-2} \mathrm{wk}^{-1}\right)$ while those that received 0 $\mathrm{t} \mathrm{ha}^{-1}$ of compost produced plants with lower net assimilation rate $\left(0.00029 \mathrm{~g} \mathrm{~cm}^{-2} \mathrm{wk}^{-1}\right)$ (Table 3). At 12WAT, application of $20 \mathrm{t} \mathrm{ha}^{-1}$ of compost produced plants with higher net assimilation rate $\left(0.00116 \mathrm{~g} \mathrm{~cm}^{-2} \mathrm{wk}^{-1}\right)$ while those that received 0 $\mathrm{t} \mathrm{ha}{ }^{-1}$ of compost produced plants with lower net assimilation rate $\left(0.00025 \mathrm{~g} \mathrm{~cm}^{-2} \mathrm{wk}^{-1}\right)$. Irrigation intervals had significant effect on net assimilation rate of onion across the sampling periods except at 12WAT, at BUK. At BUK, irrigation at 10 days interval produced plants with higher net assimilation rate $\left(0.00103 \mathrm{~g} \mathrm{~cm}^{-2}\right.$ $\mathrm{wk}^{-1}$ ) although statistically at par with 5 days interval $\left(0.00099 \mathrm{~g} \mathrm{~cm}^{-2} \mathrm{wk}^{-1}\right)$ while those that received 15 days of irrigation interval produced plants with lower net assimilation rate $(0.00031 \mathrm{~g}$ $\mathrm{cm}^{-2} \mathrm{wk}^{-1}$ ) (Table 3). However, at Birji, at 8WAT, a similar trend was observed (Table 3). At 12WAT, at the same location, irrigation at 5 days interval produced plants with higher net assimilation rate $\left(0.00100 \mathrm{~g} \mathrm{~cm}^{-2} \mathrm{wk}^{-1}\right)$ although statistically at par with 10 days of irrigation interval $\left(0.00090 \mathrm{~g} \mathrm{~cm}^{-2} \mathrm{wk}^{-1}\right)$ while those that received 15 days of irrigation interval produced plants with lower net assimilation rate $(0.00015 \mathrm{~g}$ $\mathrm{cm}^{-2} \mathrm{wk}^{-1}$ ) (Table 3). The interaction between compost rates and irrigation intervals was significant on net assimilation rate of onion across the sampling periods except at 12WAT, at BUK (Table 3).

Table 4 shows the effect of compost rates and irrigation Intervals on cured bulb yield of onion at BUK and Birji during 2017 dry season. There were significant differences between compost rates on cured bulb yield at both locations. At BUK, Application of $15 \mathrm{t} \mathrm{ha}{ }^{-1}$ of compost produced plants with heavier cured bulb yield $\left(2.91 \mathrm{t} \mathrm{ha}^{-1}\right.$ ) while those that received $0 \mathrm{t} \mathrm{ha}^{-1}$ of compost had produced plants with lighter cured bulb yield (1.64 t ha-1) (Table 4). However, at Birji, application of $10 \mathrm{t} \mathrm{ha}{ }^{-\mathrm{I}}$ of compost had produced plants with heavier cured bulb yield (8.99 $\mathrm{t} \mathrm{ha}^{-1}$ ) while those that received $0 \mathrm{t}$ ha ${ }^{-1}$ produced plants with lighter cured bulb yield (5.24 t ha ${ }^{-1}$ ) (Table 4). Irrigation intervals had no significant effect on cured bulb yield of onion at both locations (Table 4). The interaction between compost rates and irrigation intervals on cured bulb yield of onion had significant effect at both locations (4). 
BAJOPAS Volume 14 Number 1, June, 2021

Table 1. Effect of Compost Rates and Irrigation Intervals on Crop Growth Rate ( $\mathrm{g} \mathrm{wk}^{-1}$ ) of Onion at Bayero University, Kano and Birji during 2017 Dry Season.

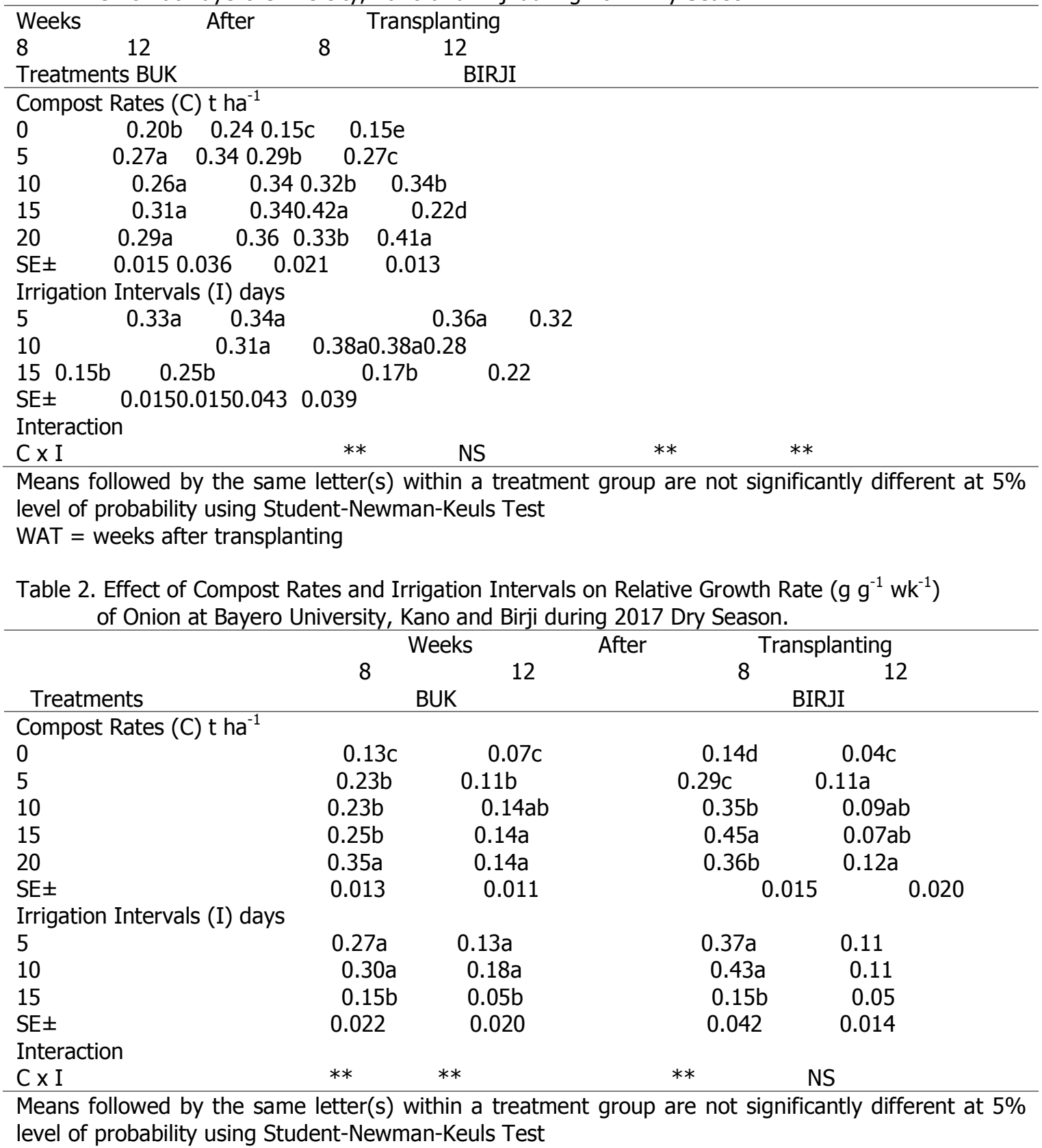


BAJOPAS Volume 14 Number 1, June, 2021

Table 3. Effect of Compost Rates and Irrigation Intervals on Net Assimilation Rate $\left(\mathrm{g} \mathrm{cm}^{-2} \mathrm{wk}^{-}\right.$ ${ }^{1}$ ) ofOnion at BayeroUniversity, Kano and BIRJI during 2017 Dry Season.

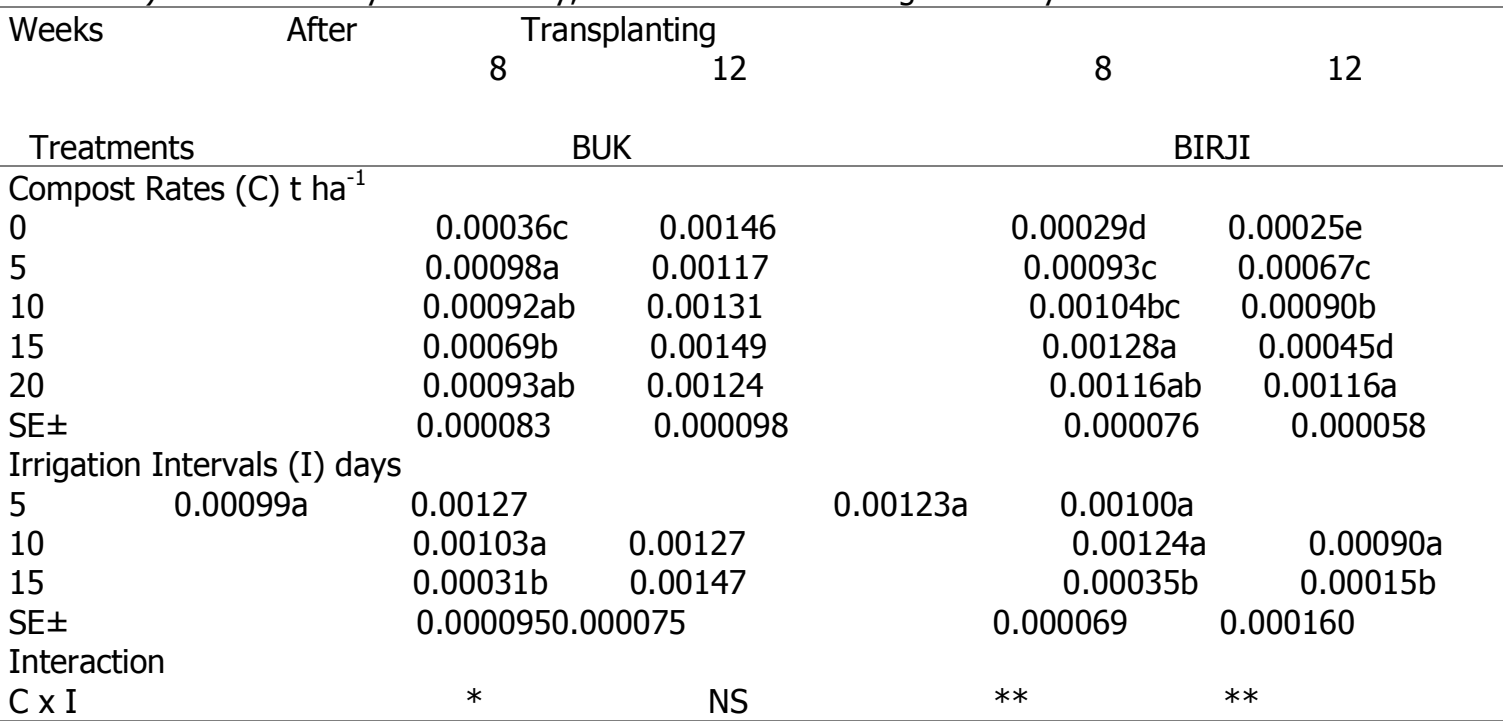

Means followed by the same letter(s) within a treatment group are not significantly different at $5 \%$ level of probability using Student-Newman-Keuls Test

Table 4. Effect of Compost Rates and Irrigation Intervals on Cured Bulb Yield ( $\left.\mathrm{t} \mathrm{ha}{ }^{-1}\right)$ of Onion atBayero University, Kano and Birji during 2017 Dry Season.

\begin{tabular}{lcc}
\hline Treatments & BUK & BIRJI \\
Compost Rates (C) t ha ${ }^{-1}$ & $1.64 \mathrm{e}$ & $5.24 \mathrm{~d}$ \\
0 & $2.29 \mathrm{~d}$ & $8.59 \mathrm{~b}$ \\
5 & $2.77 \mathrm{~b}$ & $8.99 \mathrm{a}$ \\
10 & $2.91 \mathrm{a}$ & $7.41 \mathrm{c}$ \\
15 & $2.50 \mathrm{c}$ & $8.37 \mathrm{~b}$ \\
20 & 0.040 & 0.081 \\
$\mathrm{SE} \pm$ & & \\
Irrigation Intervals (I) days & 2.70 & 8.11 \\
5 & 3.05 & 7.94 \\
10 & 1.52 & 7.12 \\
15 & 0.442 & 0.340 \\
SE \pm & $*$ & $*$ \\
Interaction & $*$ & \\
C I & &
\end{tabular}

\section{DISCUSSION}

Higher crop growth rate (CGR)observedas affected by compost rates could be due to the fact that nutrients became more available with increase in the quantity of compost up to the highest rate. As per this experiment, the higher relative growth rate (RGR)observed as compost increased up to the highest rate could also due to the beneficial effect of the organic fertilizer was an evident with remarkable increase in relative growth rate with increasing compost rate in comparison with the control plots. The result obtained was in support with the findings of Soliman (1999) who showed that the maximum values for relative growth rate was reached at the end of garlic shoot growth stage. The significant differences observed for compost rates on NARduring the crop growth stages from 30-60 to 60-90 days after sowing might be related to the rapid bulbs developments as a result of more sinks as reported by Rahman et al.,(2013). They also added that during bulb growth stage, there were increases in bulb dry weight. The heavier cured bulb yield of onion observed as influenced by compost rates could be attributed to the role of organic fertilizer as valuable as sources of many essential macro and micronutrients to plants. 
It also increase availability and uptake of nitrogen, phosphorus and potassium which positively reflected on plant cell elongation and division as well as stimulate photosynthesis and metabolic processes of organic compounds in plant, thus increasing total bulbs yield ha' ${ }^{1}$.Sarsavadiaet al., (1999) reported that application of organic manures resulted in higher bulb yields in comparison with their unfertilized counterpart. This result supported the findings of Salem (2012). Broner (2005)reported that organic manure is a supplier of N, P and K in the soil, which also increased the phosphate solubilizing bacteria in the rhizosphere. This result was in line with the findings of Mofuka et al., (2007) who reported that application of farmyard manure at $20 \mathrm{t} \mathrm{ha}^{-1}$ produced maximum yield of onion bulbs $\left(36.7 \mathrm{t} \mathrm{ha}^{-1}\right)$ as compared to control $\left(28.7 \mathrm{t} \mathrm{ha}^{-1}\right)$ followed by application of vermin compost at $5 \mathrm{t} \mathrm{ha}^{-1}$ which produced the bulb yield of $23.30 \mathrm{t} \mathrm{ha}^{-1}$. Higher CGR and RGR observed as irrigation interval increased up to 10 days might be due to rapid bulbs development as sinks increased but they declined in the crop growth rate in this period (15 days) could be due to aging and the loss

\section{REFERENCES}

Amans, E.B. (1989). Effect of intra-row spacing and nitrogen application on early and late sown irrigated onions. 1. Growth and bulb yield. Ph.D. Seminar, pp: 38.

Alam, M. M. (2006).Performance of Low Cost Sprinkler Irrigation System of Onion Cultivation. Research Report of Spice Research Center, BARI, Bogra. pp. 8285

Broner, I. (2005). Irrigation Scheduling. Crop Series on Irrigation. Colorado State University Cooperative Extension. Publication no. 4.704.p 1

Chowdhury, R. (2004). Effects of chemical fertilizers on the surrounding environment and the alternative to the chemical fertilizers IES- ENVIS NEWSLETTER, 7(3): 4-5.

Doro, A.K. (2012) Effect of irrigation interval on the yield of garlic (Allium sativumL.) at ajiwairrigation.JORIND10 $\quad$ (2):15968308.

El-Sahookie, M. M, Alfalahi, A.O, Almehemidi, A. F (2009). Crop and Soil Management and Breeding for Drought Tolerance. Iraq. J. Agric. Sci. 40(2):1-28.

Hasegawa, A., Yabuki, H., Nabeura, T., FukuI, H. and Iwata, T. (2001).Evaluation of bulb shape and fresh weight of different leaves at the end of the growing season as reported by Rahman et al., (2013). The significant differences observed for irrigation intervals on net assimilation rate (NAR) implied that lower irrigation interval resulted into heavier dry weight which leads to increase in NAR. The significant differences observed for irrigation intervals on the average bulb weight and fresh bulb yield of onion implies that less frequent irrigation could be attributed to more number of leaves and higher LAI and hence, heavier bulb yield. This result supported the findings of Alam (2006) who observed the highest yield of onion at 5 days irrigation interval. Doro, (2012) also reported highest bulb yield of onion from 5 days intervals followed by 10 and 15 days of irrigation.

\section{CONCLUSION}

Compost is one of the most economically viable ways to incorporate a wide range of macro and micro-nutrients in to the soil. To achieve a high yield potential of onion, appropriate soil moisture should be maintained during entire growing season.

onion cultivars. Tech. Bull. Agric. KagawaUniv. 53, 71-77.

Mofuka, M. M., Nsomb, M., Nkasa C., Ibwenzi, K and Taba, K. (2007).Effect of combining organic biomass and inorganic fertilizer on tomato yield and nematode control in Arenosal in Kinshasha. In: A Betonoed (ed). Advances in Integrated Soil Fertility Management in sub-Saharan African.Challenges and Opportunities. 359-363.

Mohamed, A., and Fahal, A. (2006). Effects of irrigation interval, sowing date and clove size on yield and some yield components of local garlic (Allium sativum L.) in the Northern Sudan. Sudan Journal of Agricultural Research, 7: 35-42.

Nuutila, A. M., Puupponen-Pimia, R., Aarni, M. and Oksman-Caldentey, K. M. (2003).Comparison of antioxidant activity of onion and garlic extracts by inhibition of lipid peroxidation and radical scavenging activity. Food Chemistry81: 485-493.

Pejic, B., Gvozdanovic-Varga, J., Milic, S., Ignjatovic-Cupina, A., Krstic, D. and Cupina, B. (2011).Effect of irrigation schedules on yield and water use of onion (Allium cepaL.). African Journal of Biotechnology Vol. 10(14), pp. 26442652. DOI: $10.5897 / A J B 10.1059$. 
BAJOPAS Volume 14 Number 1, June, 2021

Available online at http://www.academicjournals.org/AJB

Rahman, M.A., Mahmud, J.A. and Islam, M.M.

(2013). Influence of mulching on the growth and yield of onion. Technical Journal of Engineering and Applied Sciences 3(24): 3497-3501.

Sarsavadia, PN.,Sawhney, RL., Pangavhane, DR., Singh, SP. (1999). Drying

behaviour of brined onion slices. J Food Eng. 1999;40:219-226. 10.1016/S0260-8774(99)00058-8.

Soliman, M.F.Z., 1999. Studies on intercropping some vegetable crops on garlic plants. M.Sc. Thesis, VegetableDept., Fac. Agric., Cairo Univ., Egypt

Table 45. Effect of Compost Rates and Irrigation Intervals on Net Assimilation Rate $\left(\mathrm{g} \mathrm{cm}^{-2} \mathrm{wk}^{-}\right.$

${ }^{1}$ ) of Onion at BUK and Birji during 2017 dry season.

Weeks After Transplanting

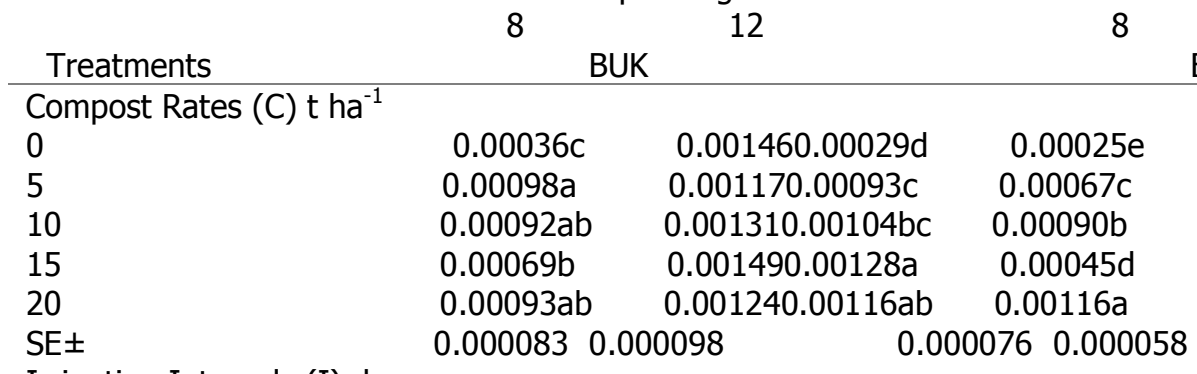

Irrigation Intervals (I) days

$\begin{array}{llllll}5 & 0.00099 \mathrm{a} & 0.00127 & 0.00123 \mathrm{a} & 0.00100 \mathrm{a} & \\ 10 & & 0.00103 \mathrm{a} & 0.00127 & 0.00124 \mathrm{a} & 0.00090 \mathrm{a} \\ 15 & & 0.00031 \mathrm{~b} & 0.00147 & 0.00035 \mathrm{~b} & 0.00015 \mathrm{~b} \\ \text { SE } & & 0.0000750 .000069 & 0.0001600 .000095\end{array}$

Interaction

$\mathrm{C} \times \mathrm{I} \quad * \quad \mathrm{NS} \quad * * \quad * *$

Means followed by the same letter(s) within a treatment group are not significantly different at $5 \%$ level of probability using Student-Newman-Keuls Test

WAT $=$ weeks after transplanting

Table 58. Effect of Compost Rates and Irrigation Intervals on Cured Bulb Yield ( $t \mathrm{ha}^{-1}$ ) of Onion at BUK and Birji during 2017 dry season.

\begin{tabular}{lcc}
\hline Treatments & BUK & Birji \\
\hline Compost Rates (C) t ha ${ }^{-1}$ & $1.64 \mathrm{e}$ & \\
0 & $2.29 \mathrm{~d}$ & $5.24 \mathrm{~d}$ \\
5 & $2.77 \mathrm{~b}$ & $8.59 \mathrm{~b}$ \\
10 & $2.91 \mathrm{a}$ & $8.99 \mathrm{a}$ \\
15 & $2.50 \mathrm{c}$ & $7.41 \mathrm{c}$ \\
20 & 0.040 & $8.37 \mathrm{~b}$ \\
$\mathrm{SE} \pm$ & & 0.081 \\
Irrigation Intervals (I) days & 2.70 & \\
5 & 3.05 & 8.11 \\
10 & 1.52 & 7.94 \\
15 & 0.442 & 7.12 \\
SE \pm & $*$ & 0.340 \\
Interaction & $*$ & $*$ \\
C $x$ I & & \\
\hline Means followed by the same letter(s) within a treatment group are not significantly different at 5\% \\
level of probability using Student-Newman-Keuls Test \\
WAT = weeks after transplanting & &
\end{tabular}

